DORIS NOVAK, Ph.D.

E-mail: doris.novak@fpz.hr

TINO BUCAK, Ph.D.

E-mail: tino.bucak@fpz.hr

TOMISLAV RADIŠIĆ, M.Sc.

E-mail: tomislav.radisic@fpz.hr

University of Zagreb,

Faculty of Transport and Traffic Sciences

Vukelićeva 4, HR-10000 Zagreb, Republic of Croatia
Transport Engineering

Preliminary Communication

Accepted: Dec. 22, 2008

Approved: Sep. 16, 2009

\title{
DEVELOPMENT, DESIGN AND FLIGHT TEST EVALUATION OF CONTINUOUS DESCENT APPROACH PROCEDURE IN FIR ZAGREB
}

\begin{abstract}
As part of Local Conversion and Implementation Plan which is based on the EUROCONTROL Revised Convention the Republic of Croatia has undertaken to make a plan of implementing the Basic Continuous Descent Approach procedures. This paper addresses the issue of navigational path optimization for the A-319/320 commercial aircraft within the fleet of Croatia Airlines, during the approach part of flight, which has a positive effect on fuel consumption, greenhouse gas emission and area of surface affected by noise. The experiments were carried out in real conditions, using internal sensors onboard (Flight Data Recorder) and independent GPS system. Two types of approach were tested: Continuous Descent Approach (CDA) and Step Down Approach. The implementation of CDA procedures, just for the fleet of Airbus 320/319 aircraft of the Croatia Airlines results in approximate calculation in fuel saving which amounts to $1.5 \times 106 \mathrm{~kg}$ annually (only on Zagreb airport). In this way, the productiveness of an air carrier, which is an integral part of the traffic process along with the airports and air traffic control, is directly increased, thus fulfilling the purpose of air traffic technology research.
\end{abstract}

\section{KEY WORDS}

navigational procedures, continuous descent approach, air traffic, ecology

\section{INTRODUCTION}

The process of transporting passengers and cargo by air is characterized by overcoming a distance in space while not being bound to a particular location in space (except some tasks such as embarkation and disembarkation of passengers, loading and unloading of cargo, etc.) [1]. By agreeing to the Local Convergence and Implementation Plan (LCIP) [2], based on the EUROCONTROL Revised Convention, all airspace users are obliged to develop and implement detailed plans for harmonization and integration of systems and services related to air traffic in accordance with the single European ATM system. Therefore, all aforementioned requirements must be in accordance with the Eurocontrol ATM 2000+ Strategy, the European Convergence Implementation Plan (ECIP), the European ATM Performance Enhancement Activities (domain/programmes), and with the Single European Sky (SES - e. g. SESAR, Common requirements, etc.).

During the process of becoming a member state of the European Union, while legislation was being synchronized between the Republic of Croatia and the European Union and legal acts of the Council of Europe, the process which was defined in the National Programme for Admission of Republic of Croatia to European Union [3], a framework for creating Single European Sky was adopted.

Based on the European Convergence and Implementation Plan (ECIP), the Croatian Civil Aviation Authority and all stakeholders, airport operators, ANS providers and all airspace users, are obliged to create a Local Convergence and Implementation Plan (LCIP) according to which the harmonization tasks will be determined. One of these tasks is ENV01: to implement Basic Continuous Descent Approach (BCDA) procedures for environmental improvements associated with approaches with continuous descent. This procedure is defined by Air Traffic Law, yet it has not been used so far and there is no plan for its implementation.

\section{RESEARCH GOALS}

Based on the previous conclusions, the Faculty of Traffic and Transport Sciences in Zagreb has proposed the development of a science and economy co- 
operative project for determining the benefits of the CDA procedures as well as their feasibility and cost-effectiveness inside the Croatian airspace (Zagreb FIR). Based on this research, a plan of implementation of the CDA procedures in accordance with ENV01 of LCIP could be made [2].

This research, partakers of which would be the air carriers (predominantly Croatian flag carrier Croatia Airlines), Croatian Air Traffic Control, airports and other interested parties (e. g. Croatian Civil Aviation Authority, Croatian Chamber of Commerce, Environmental Protection Fund), would have two main goals:

- reducing the greenhouse gas emission during the approach for landing,

- reducing the aircraft noise footprint during the approach for landing.

Secondary goals of this research - with direct effect on commercial sector - are the following:

- to prove the effectiveness of the CDAs over standard approaches in terms of reducing noise footprint and greenhouse gas emissions,

- to develop operating procedures for the usage inside Zagreb FIR which would make the CDA possible with regards to air traffic capacity,

- to reduce the total fuel consumption of the Croatia Airlines Airbus 319/320 fleet during the approach for landing,

- to develop operating and approach procedures within the air carrier company as a recommendation for crews with the goal of reducing fuel consumption during the approach for landing at domestic and international airports,

- to fulfil the ENV01: Implement Basic Continuous Descent Approach (BCDA) requirement of the Local Convergence and Implementation Plan (LCIP).

The concept of CDA has been operational for many years. With the conventional landing approach, aircraft are given clearance by ATC from the bottom level of the holding stack (usually an altitude of $7,000 \mathrm{ft}$ ) to descend to an altitude of 3,000ft. This altitude is reached normally by step-down descent, with aircraft descending and then flying level flight for several miles before next descent and levelling out again. Once the aircraft reaches the final approach course and glide path angle of $3^{\circ}$ to the runway (from 3,000ft) it begins a continuous approach to landing. In contrast to the conventional approach, the CDA positions the aircraft at its most effective cruise altitude until it is relatively close to the airport. At this point the aircraft reduces engine thrust to idle and begins a descent to the runway continuously. In this manner, the aircraft stays higher for a longer period of time saving fuel burned during the cruise at higher altitudes. In addition, during the conventional approach the pilots need to apply extra thrust to maintain constant speed in level flight approach segments at lower altitudes which burns additional fuel and creates a larger noise footprint on the ground. With CDA there is no variation in engine thrust while the aircraft maintains $3^{\circ}$ glide path angle approach.

\section{EXAMPLES SUPPORTING THE RESEARCH}

Noise produced by aircraft during the take-off and approach for landing has become a critical constraining factor at many European airports. The main reasons for this are the constantly growing populated areas around the airports combined with the intensified air traffic, leading to increased public awareness and reaction to aircraft noise [3].

The noise abatement operational procedures used today ensure lower levels of aircraft noise during the take-off and landing and can be divided into three broad categories [4]:

- noise abatement flight procedures: Continuous Descent Approach (CDA), Noise Abatement Departure Procedures (NADP), Low Power/Low Drag approach profiles (LP/LD), modified angles of approach and reduced usage of reverse engine thrust during braking;

- spatial management;

- ground management.

The Continuous Descent Approach is a noise abatement procedure for the arriving aircraft in which the pilot selects the most efficient rate of descent on the path to Final Approach Point, where the procedure for instrument landing begins (ILS approach). This path enables the aircraft to fly without major corrections of engine thrust, which is at the minimum from the start of the procedure, thus reducing fuel consumption from the beginning of the descent until the start of the final approach phase (1000ft above ground level).

The ICAO stresses the need to continue the development on noise abatement procedures, especially on CDA which brings, along with noise reduction, the reduction of the greenhouse gas emissions [4]. These benefits include:

- 3 to $12 \mathrm{~dB}$ noise reduction and $8 \%$ to $36 \%$ reduction in noise contour areas on approach,

- as much as $35 \%$ reduction in $\mathrm{CO} 2, \mathrm{HC}$ and $\mathrm{NOx}$, and 25 to $500 \mathrm{~kg}$ savings per landing,

- 90 to $630 \mathrm{~kg} \mathrm{CO} 2$ and 30 to $220 \mathrm{~kg}$ fuel savings per departure.

The main goal of applying the CDA procedures is to help pilots optimize their flight profiles on approach in order to reduce noise and greenhouse gas emissions. In other words, this procedure tries to keep aircraft as high as possible for as long as possible and 
then uses the selected approach profile with minimum corrections in approach path.

Since $\mathrm{CO}_{2}$ emission is directly proportional to the consumed fuel (3.15 tons of $\mathrm{CO}_{2}$ per ton of used fuel), it is also going to increase by $57 \%$ by the end of 2015 . These predictions do not include general aviation and military aircraft (NATO forces are equipped with more than 12,000 aircraft). Therefore, these predictions can be increased by further 8 to $20 \%$.

The research conducted in cooperation with EUROCONTROL has shown a $40 \%$ decrease in fuel consumption during the approach for landing (fleet of Airbus 320s and ATRs). In other words, depending on the altitude at which the procedure is being applied from 50 to $150 \mathrm{~kg}$ of fuel can be saved. Expressed in the relation of prices from the year 2007 this means a saving of 50-100 million euro per year [4].

With the aviation industry concerned with the recent rapid rise in the fuel prices, the CANSO, Eurocontrol and IATA have identified a series of short-term measures that together will reduce the annual fuel consumption by 470,000 tonnes [5]. The measures are mainly in two areas: to ensure a tangible improvement of the European airspace design for both en-route and terminal areas, and to ensure a tangible improvement to airspace and airport utilization. Together they should result in an annual reduction in $\mathrm{CO}_{2}$ emissions of $1,555,000$ tonnes each year and saving in the airlines fuel bill in the region of $€ 390$ million. The five action points of the Flight Efficiency Plan are:

1. enhancing the European en-route airspace design through annual improvement of the European ATS route network;

2. improving airspace utilization and route network availability;

3. efficient TMAs design and utilization through implementing advanced navigation capabilities,
CDA and improved arrival/departure routes, optimized departure profiles etc;

4. optimising airport operations through implementation of Airport Collaborative Decision Making;

5. improving the awareness of performance.

This plan will be implemented with IATA members airlines, the air navigation service providers, airports, the army and the States. It comes in addition to the substantial efforts that have been made over the past nine years by all participants in air traffic together with Eurocontrol to improve the performance of the European air traffic management network.

\section{RESULTS OF THE PRELIMINARY STUDIES}

Two scheduled flights from Split to Zagreb have been flown inside the Zagreb FIR and TMA by Airbus 319 aircraft of the Croatian flag carrier Croatia Airlines. The goal of this study was to demonstrate the benefits of the CDA in terms of reducing fuel consumption (implying the reduction of the greenhouse gas emissions) and decreasing noise during the intermediate approach phase of flight (Figure 1).

The results of these studies, presented at the Inter-noise08 [6] Congress showed through simulation a $35 \mathrm{~kg}$ reduction of fuel consumption by using CDA during the approach for landing. In-flight experiments with Croatia Airlines A319, conducted in similar conditions as the simulated flight, showed a $150 \mathrm{~kg}$ reduction of fuel consumption per approach. The possible cause for sufficient difference between the simulation results and the flight test results are in the International Standard Atmosphere conditions, which were the base assumptions for the conducted simulations. The real conditions during flight deviate to a certain extent from the standard conditions, in term of

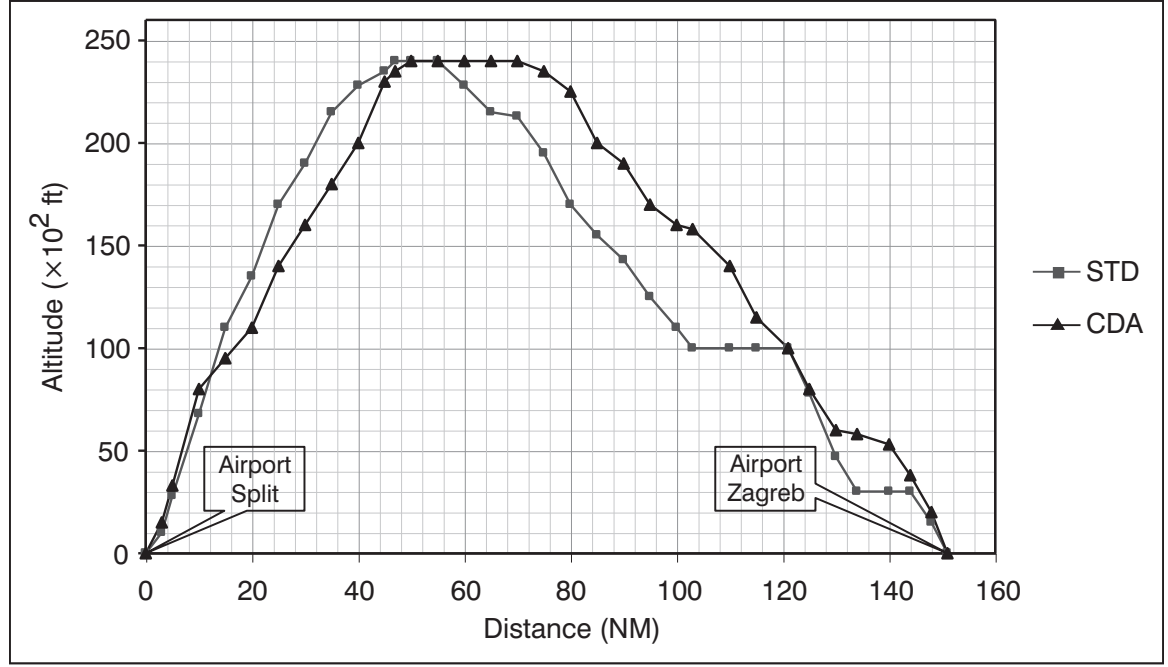

Figure 1 - Standard approach and continuous descent flight profiles 
temperature and pressure gradient change, which may influence the final results. These facts are to be evaluated in the future flight trials and experiments.

In accordance with the operative experience of CTN and the standard operative procedures of air traffic control (ATC), for the first simulation the calculation of the standard flight profile was taken on the Split - Zagreb flight in the total duration of $32 \mathrm{~min}$ utes. The flight was planned for aircraft Airbus 319 with actual take-off mass of $52,800 \mathrm{~kg}$. The first segment included climbing to the planned FL240 at an angle of $4.7^{\circ}$ (climb gradient $8.2 \%$ ) in the duration of nine minutes at a distance of $48 \mathrm{NM}$ from take-off to TOC (Top of Climb). The cruising segment from TOC to TOD (Top of Descent) is planned for 7NM in the duration of one minute, followed by the descent to FL100 in the duration of eight minutes (48NM, descent $4.8 \%$ ). At FL100 horizontal flight segment is planned in the duration of four minutes (18NM) followed by a repeated segment of descent (13NM) to the altitude of 3,000ft AGL at an angle of $5^{\circ}$ (descent gradient $8.8 \%$ ) in the duration of three minutes. Horizontal segment at 3,000ft AGL is planned for three minutes of flight i. e. 10NM, followed by the final approach to landing at the Airport Pleso - Zagreb at an angle of $3^{\circ}$ (ILS approach). In accordance with the actual meteorological data for the days of the planned flights the data were input on the head/tail wind component at different flying altitudes. Based on such flight profile and actual take-off mass of $52,800 \mathrm{~kg}$ at take-off, the aircraft mass after landing (actual Landing Mass) of $51,507 \mathrm{~kg}$ has been calculated. The difference between ATOM and ALM forms the consumed fuel during flight i. e. $1,293 \mathrm{~kg}$.

The second simulation took into consideration the CDA with FL240, with the same assumptions of ATOM and the direction and intensity of wind at different altitudes. The first segment of climb to FL240 started with the aircraft mass of 52,800kg, and 11 minutes passed until TOC was reached covering the distance of 39NM. The horizontal segment from TOC to TOD at FL240 took four minutes, i. e. 20NM, followed by simulation of a continuous angle of descent to the ground of $2.75^{\circ}$ (descent gradient $4.8 \%$ ). The segment took 17 minutes or $82 \mathrm{NM}$. The total duration of flight was, like in the first simulation, 32 minutes, i. e. a total of 151NM travelled. The aircraft mass upon landing according to this profile amounted to $51,542 \mathrm{~kg}$, which is $1,258 \mathrm{~kg}$ of consumed fuel. The difference of $35 \mathrm{~kg}$ in fuel saving during flight occurred in the second simulation by using a continuous angle of descent in the third route leg.

Based on the performed simulations that can roughly present the expected results, according to input assumptions of the simulated situations, tests and measurements were carried out on two flights by A319 aircraft of Croatia Airlines, in approximately equal meteorological conditions on scheduled flights (the simulation was carried out on 05 March 2008, and the flights on 06 and 07 March 2008 taking off from Split at the same time). Measurements during flight were carried out by GPS Garmin 496 and the results were processed in Ozi Explorer software using geo-coded maps of the Republic of Croatia.

The first flight on 06 March 2008 was performed according to the standard operative procedure at ATOW of $52,800 \mathrm{~kg}$,

The second flight took place on 07 March 2008, when the weather conditions were approximately the same but since, due to economical reasons, the testing could be performed only on a scheduled flight when passengers are transported, ATOW on the second flight was greater and amounted to $58,200 \mathrm{~kg}$, which makes the aircraft during the second flight by $5,400 \mathrm{~kg}$ heavier. On the second flight the crew implemented the CDA technique from TOD FL240 until entering ILS - with special agreement and coordination with the ATC centre.

Deriving from the meteorological data, the engine thrust, angle of approach and land surface around the final approach fix, a simulation of the noise footprint was made for the CDA and the standard approach. This simulation was done by using the Integrated Noise Model (INM) software which is used for making noise contour charts at the Zagreb-Pleso airport.

\section{RECOMMENDED PLAN OF IMPLEMENTATION}

Based on the aforementioned, the Department of Aeronautics of the Faculty of Transport and Traffic Sciences recommends a plan for the implementation of CDA procedures which will be carried out by all airspace users and service providers joined in a technological project.

This plan will be based on the current CDA benefits research and the methodology already mentioned in this document.

In accordance with the Eurocontrol recommendations [7], the following Key Requirements for Success are necessary for the efficient implementation of the CDA procedures:

- A preliminary review made by operational stakeholders to establish whether changes to procedures will lead to environmental enhancement and operational/economic benefit and to assist in planning such changes.

- A positive safety and cost/benefit review including the use of simulators to assess at an early stage whether CDAs are operationally possible. 
- Commitment from the senior management of operational stakeholders.

- Willingness to change operational practice to benefit the local residents and aerodrome as a whole.

- Support from regulator(s) will also assist implementation.

- Effective collaboration.

- Adequate ongoing promotion, training, performance monitoring and performance feedback to all those involved as part of a continual improvement process.

The CDA is a tactical procedure and it is not expected that it will be successfully applied by every aircraft on approach at a particular aerodrome. As experience grows, the number of aircraft using CDA should increase to a significant proportion of flights.

Generally, the implementation plan would have four phases:

1. Initial phase: it would encompass initiation, informal preliminary consultations with the airspace users and service providers, and preparation of a detailed study. After that, the regulator (Ministry of Transport) would form a task group whose purpose would be to draw a plan for the next phase. As the final product of the first phase, a booklet would be published with suggested CDA procedures for Zagreb FIR and with the results of the domestic and international scientific research regarding CDA.

2. The planning phase: it would include detailed review of the existing situation regarding approach procedures, joint agreement on the CDA variant for the Zagreb FIR, designing CDA solution, strategic planning of the CDA utilisation and jointly agreed implementation, development and reporting plan.

3. Implementation phase: based on the agreed CDA variant and implementation plan, manuals and training materials would be made as well as simulation, validation and assessment of the CDA procedure. After simulations and assessment have shown positive results, the CDA procedure would be made operational.

4. Review phase: the purpose of this phase would be to enhance the procedure through feedback from all participants. Improvements would be implemented and reviewed.

The outline of the implementation plan is shown in Figure 2.

Although some planned activities are specific and specialized, the CDA procedure implementation can only be achieved through collaboration between all operational stakeholders (air carriers, CroControl and airports).

The stakeholders have a collective responsibility to ensure that:

- The implementation plan is in accordance with Eurocontrol recommendations (deviating from them as little as possible).

- Regulatory authorities support CDA implementation, ensure harmony with any national plans and

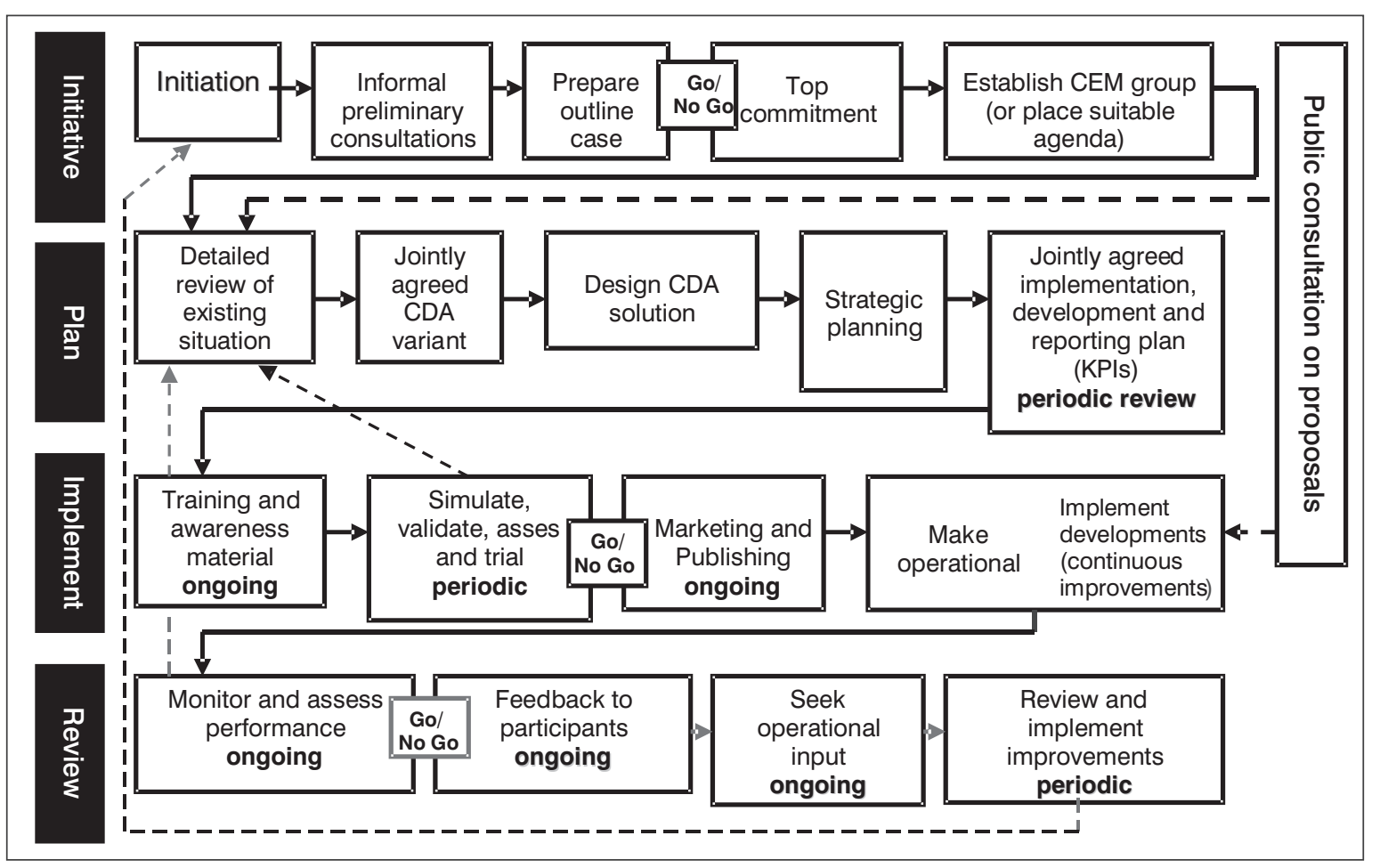

Figure 2 - Generic CDA implementation plan [7] 
the flow of information. This should be done through consultations at an early stage.

- All proposed CDA procedures are subject to adequate and integrated safety assessment before implementation.

- At an early stage of implementation, initial CDA review is conducted, which should answer the following questions:

- Does implementation meet the 'Key Requirements for Success'?

- Do arriving aircraft presently fly segments of level flight above noise sensitive areas at less than $10,000 \mathrm{ft}$ ?

- Will implementation of CDA reduce the noise impact on these areas?

- Can operating procedures be changed without generating safety or operational problems?

- Senior management from each stakeholder organisation takes an active leadership interest in CDA implementation and releases adequate resources including nominating 'CDA points of contact'.

It is very important that all individual and collaborative responsibilities and tasks are coordinated through the Collaborative Implementation Group (CIG). This group is made of representatives from all stakeholder organisations with the primary goal of coordinating implementation activities and informing all stakeholders, and other interested parties, of individual roles and tasks, roles and tasks of other stakeholders and tracking current status of the implementation.

Generally, the roles and tasks of stakeholders during the CDA implementation process can be divided as follows:

1. State and Regulator role: strategic planning of the airspace use in terms of implementing CDA procedures, marketing and support of the CDA implementation plan as a way of protecting the environment, support during the modification of operating procedures and production of safety reviews and recommendations.

2. Air Navigation Service Provider role: all relevant ATC staff should receive adequate awareness briefing and continuation training to allow them to continue to facilitate CDA (particular attention should be given to assessing distance-to-go and the use of speed control).

3. Aircraft Operator role: proactive role in the implementation and the use of simulators to assess the proposed CDA associated with $\mathrm{LP} / \mathrm{LD}$, review company Standard Operating Procedures, encourage pilots to apply the CDA techniques in order to minimise the horizontal flight segments during the approach, optimise the descent profile and minimise airframe and engine noise.
4. Aerodrome Operator role: providing local strategic advice and policy guidance around the aerodrome, noise monitoring during the approaches to support performance management, actively inform local community of the environmental benefits of the CDA procedures.

As illustrations of importance for the necessary development and implementation of proposed plan during August 2008 Eurocontrol and IATA have agreed a five-point plan to reduce fuel burn and emissions [5]. With the aviation industry concerned with the rapid rise in the price of fuel, the organizations have identified a series of short-term measures that together will reduce annual fuel consumption by 470,000 tonnes. The measures point at two general areas: to ensure improvement of the European airspace design for both terminal and en-route areas, and to ensure improvement to airspace and airport utilization. Together they should result in an annual reduction in $\mathrm{CO}_{2}$ emissions of 1,555,000 tonnes each year and saving in the airline fuel in the region of EUR 390 million. The five-point action plan consists of:

- Enhancing European en-route airspace design through annual improvement of European ATS route network, high priority being given to the implementation of a coherent package of annual improvements and supporting initial implementation of free route airspace,

- Improving airspace utilisation and route network availability through actively supporting and involving aircraft operators and the computer flight plan service providers in flight plan quality improvements and improving the utilisation of civil/military airspace structures,

- Efficient TMAs design and utilisation through implementation of advanced navigational capabilities, implementation of CDAs and improved arrival/departure routes and optimised departure profiles,

- Optimising airport operations through implementation of Airport Collaborative Decision Making,

- Improving awareness of performance.

\section{AIRBUS PERSPECTIVE TO CDA APPROACH}

Airbus considers that noise abatement procedures are a very valuable tool, which has high potential for delivering efficiently significant noise reduction [8]. They also expect a significant development of such procedures in the coming years based on the following basic facts:

- Airports and operators have an urgent need and willingness to solve local noise problems; 
- Noise abatement operational procedures are one of the four principal elements of the balanced approach;

- Important specific research efforts in Europe and US are conducted in order to reduce noise and to develop operational noise abatement procedures;

- The development of aircraft systems is creating new opportunities (e.g. Flight Management System);

- ATC system development, etc.

In this context, the potential short-term relief that noise abatement procedures can bring, is playing a crucial role. Airbus is very active in research related to this subject and to the associated enhanced aircraft systems. Based on the above, Airbus has to integrate into all its work related to improved noise abatement operational procedures the multiple factors involved (safety first!) and to coordinate with all other actors concerned.

\section{LINK BETWEEN CDA AND AREA NAVIGATION (RNAV)}

Area Navigation (RNAV) is a method of navigation which permits aircraft operation on any desired flight path within the coverage of station-referenced navigation aids or within the limits of the capacity of self-contained aids, or a combination of these [9]. RNAV system allows the a/c to be navigated to the required level of accuracy without the requirement to fly directly over ground-based facilities.

EUROCONTROL believe that the key to successful introduction of the CNS/ATM concept is the design, development and implementation of RNAV. The performance Based Navigation (PBN) concept specifies RNAV system performance requirements in terms of accuracy, integrity, availability, continuity and functionality needed for the proposed operations in the context of a particular Airspace Concept - when supported by the appropriate navigation infrastructure. In this context, the PBN concept represents a shift from sensor-based to performance-based navigation.

The benefits of the PBN are:

a) Direct flight path;

b) Reduced congestion;

c) Reduction in distance, flight time, costs;

d) Improved flexibility;

e) Increase in route capacity, full use of available airspace;

f) Reduction in vertical and horizontal separation criteria.

As a European RNAV Application Basic RNAV (B-RNAV) is defined as RNAV that meets a lateral track keeping accuracy equal to or better than $+/$ -
$5 \mathrm{NM}$ for $95 \%$ of the flight time [9]. This value includes signal source error, airborne receiver error, display system error, and flight technical error. This navigation performance assumes the necessary coverage provided by satellite or ground-based navigation aids are available for the intended route to be flown.

As further development of the concept of area navigation within the European region, the ECAC Navigation Strategy [10] calls for the implementation of Precision Area Navigation (P-RNAV) in terminal and en-route airspace. This implementation of P-RNAV is logical development of the Basic Area Navigation (B-RNAV) as currently applied en-route and to some designated feeders into and out of terminal airspace.

The term P-RNAV refers to the RNAV routes which require that aircraft shall be equipped with, as a minimum, RNAV systems capable of meeting $+/-1 \mathrm{NM}$ lateral track keeping accuracy for at least $95 \%$ of the flight time [9]. Obviously, the functional requirements of the RNAV systems that support this kind of route are significantly greater than those corresponding to B-RNAV.

Precision Area Navigation (P-RNAV) is being introduced to enable RNAV applications to be introduced in terminal airspace. P-RNAV requirements will be published for many SIDs, STARs and Initial Approach segments where the Authorities have determined that benefit can be gained from the use of RNAV in terminal airspace. P-RNAV requirements may also be published for selected parts of the en-route structure where capacity benefits can be identified. P-RNAV can be achieved using inputs from DME/DME or GPS (IRS may be used in a reversion mode for a few minutes).

In 1999, ICAO published the RNP Manual [10], and industry developed the term RNP-RNAV. RNP RNAV was a term and concept developed by the Radio Technical Commission for Aeronautics [11] that integrated the concepts of RNP with those of RNAV. It referred to the system and the navigation performance accuracy necessary for operation within a defined airspace. Unfortunately, as global RNAV applications grew, different regions used different terms to describe the same application; due to insufficient description of the navigation performance and operational requirements, there was little perceived difference between RNAV and RNP. To eliminate any confusion, ICAO introduced the Performance Based Navigation concept and the PBN Manual [9] has superseded the RNP Manual.

An RNP application will still stipulate a lateral track-keeping accuracy requirement depending on the operation it is designed for. However, on-board performance monitoring and alerting is the main element which determines if the navigation system complies with the necessary safety level associated to an RNP 


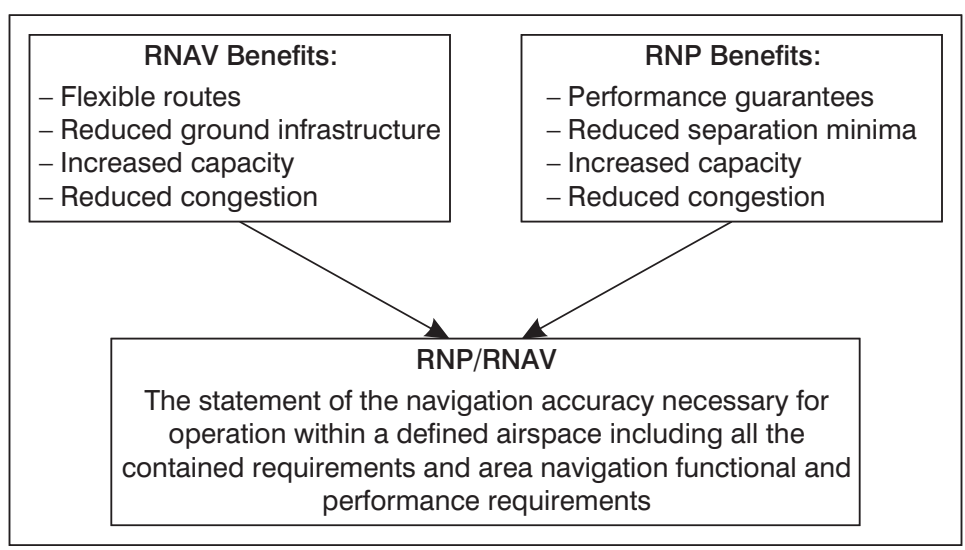

Figure 3 - RNP/RNAV benefits

application; it relates to both lateral and longitudinal navigation performance. RNP systems provide improvements on the integrity of operation and therefore may offer safety, operational and efficiency benefits (Figure 3).

Whilst the present applications are restricted to 2D RNAV, as capacity benefits can be demonstrated, they will extend to $3 \mathrm{D}$ navigation, enabling profile management to be employed and a resulting modification to the structure of TMA. The term 3D RNAV refers to the RNAV operations using the vertical co-ordinate. This kind of area navigation is an improvement of the B-RNAV/P-RNAV due to the inclusion of the altitude information in the navigation solution.

Similarly, the 4D RNAV concept is an improvement of the 3D RNAV from the use of a fourth co-ordinate, the time. 4D RNAV operations will allow a redistribution of responsibilities between aircraft and ATC. In order to implement 4D RNAV operations it is necessary that the controller support tools such as trajectory prediction, conflict resolution and arrival/ /departure managers must be in place and data-link must be available to permit the ATM system capacity to approach more closely and consistently the system optimum.

The objective of the implementation of Free Routes is to support increased flexibility of en-route operations and to improve user preferred trajectories. The Free Routes concept allows aircraft with RNAV systems to plan flights between en-route points at the beginning/end of the Terminal Procedures or the entry/exit points to the Free Routes airspace. This concept is expected to contribute to the flexibility of enroute operations, to give capacity increases, and to allow fuel and time efficient operations with the minimum ATC constraints. The initial application was based on B-RNAV capability. No additional equipment fit will be required and the requirements for navigation infrastructure remain unchanged from this point of view. The development of the Single European Sky (SES) through the ATM Research program (SESAR) introduces the concept of business/mission trajectories i. e. flight routes created for a special mission which will be based on 4D capabilities. The business trajectory is one which the airspace user agrees to fly and the ANSP agrees to facilitate (subject to separation provision). The authorization takes the form of clearance by the ANSP or validation by the aircraft (crew/systems) depending on who is the designated separator. The trajectory can be considered as having four parts:

- The executed part (RBTX): represents the already flown part of the trajectory.

- Current position (CP): the 3D position of the aircraft at a given time.

- Authorized part (RBTA): represents those segments of the trajectory (including ground segments) that have been cleared by the ANSP or validated by the aircraft within a defined horizon.

- Planned part (RBTP): segments from the limit of authorization to trajectory end.

RNAV system integrates information from the sensor to perform the following functions (Figure 4):

- Navigation (computing data - position, velocity, track angle, vertical flight path angle, drift angle, magnetic variation, wind direction and speed);

- Flight Plan Management (creation and assembly of lateral and vertical flight plan. Specification of waypoints using $\lambda, \varphi)$;

- Guidance and Control (generates steering commands used to fly the a/c along the desired path;

- Display and System Control (provide the means for system initialization, flight planning, path deviations, progress monitoring, active guidance control, presentation of navigation data for crew);

The CDA saves approximately $300 \mathrm{~kg}$ per approach [13]. Of course, these figures are specific to the aircraft type and other parameters and are based on limited data, but reflect the potential benefits of the implementation of approach procedures based on RNAV.

A higher thrust implies not only higher fuel consumption but also greater noise. 


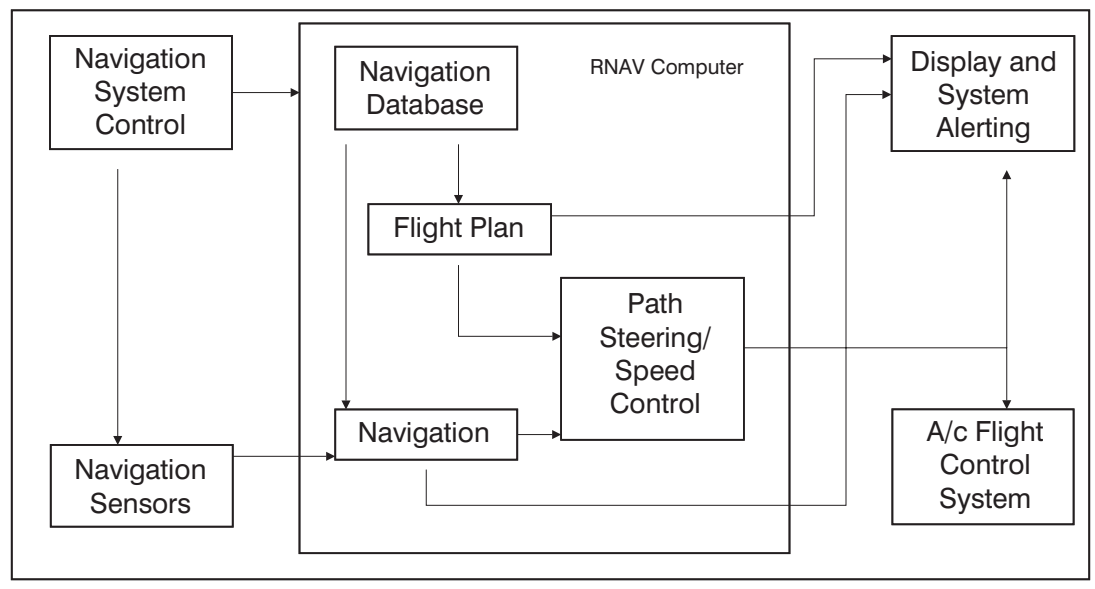

Figure 4 - RNAV system functions

The ERA (European Regions Airline Association) has established the following estimates: assuming an annual figure of 2,200 landings, of which $25 \%$ are flown using CDA rather than conventional step-down approach, the annual savings (fuel and the cost of carbon emissions) could equal to around EUR13,000 to 15,000 per aircraft. Additionally, 90 tonnes of $\mathrm{CO}_{2}$ generation would be avoided annually per aircraft and aircraft maintenance costs would be marginally reduced [13].

The concept of Required Navigation Performance will define equipment requirements for performance of aircraft in a particular airspace or phase of flight [14]. This will have a significant impact not only on the equipment carriage but also on airspace planning and development of infrastructure.

\section{AREA NAVIGATION IN CROATIA}

Modelling of the development of air traffic of the Republic of Croatia is in direct correlation with the actual reform of the European ATM as well as with the economic transition within the process of integration into the European Union. The establishment of the European Aviation Safety Agency (EASA) which is based on the upgrade of the JAR system will legally impose the safety regulation regime of airspace on the ECAC member countries.

On the other hand, apart from the harmonization activity of CNS/ATM of national systems and the implementation of ATM Strategy 2000+ through EATM projects, Eurocontrol has taken over the standardization of safety aspects of ATM. In this way the infrastructure and transport capacities should be included in the modelling of air traffic development in the Republic of Croatia, which includes airports, air traffic control system and fleet, administration-organization structure and norms.

This concept includes also the implementation of the entire series of novelties into the airspace control system in the Republic of Croatia, in which the RNAV routes form only one part [15]. The concept of conventional navigation that had been used until 2000 relied on routine navigation guidance by the ATC (Air Traffic Control). The implementation of RNAV routes, especially in the upper airspace, greater flexibility and navigation accuracy have been achieved and the capacities of all ATC sectors within the Zagreb FIR have been increased.

The RNAV routes and procedures represent the cornerstone for the realization of the PNB concept (Performance-Based Navigation) whose development plan requires defining of standards for RNP (Required Navigation Performance) as significant part of introducing the next generation of communication, navigation, surveillance in ATM (CNS/ATM). The accuracy of RNP and its integrity monitoring capability are expected to further enhance the navigational precision of RNAV and to define aircraft flight paths within tightly specified airspace corridors, and consequently, in Croatia, as the next step, gradual introduction of P-RNAV procedures for navigation guidance within the terminal airspace is expected.

It is shown that CDA could produce major benefits in costs, fuel consumption, environmental impact and the public image of aviation. Unfortunately airspace constrains or overriding safety requirements mean that it is not always possible to implement CDA, but regional airports are less complex and therefore offer more opportunities to introduce this method of approach. Some of the basic operational issues for airport can be that the runway exit points should be designated and located to help minimise the use of reverse thrust and runway occupancy times thus reducing the possibility of missed approach procedure. Also, airport should (where practicable) consider evaluating the costs and benefits of potential design enhancements, such as displaced thresholds. Successful CDA is significantly assisted by the installation of an ILS, so airports are encouraged to provide ILS to all approaches where CDA is expected. When the ILS 
is unserviceable or is not provided, the request to achieve CDA is not negated. Consideration should be given to the establishment of P-RNAV approach procedures with vertical guidance (APVs) [16] as the primary backup to ILS failure in preference to VOR, VOR-NDB, NDB or visual approach. In situations where the ILS is not available, which are rare, greater achievement of CDA is likely if P-RNAV APV procedure is in place.

It would seem that the European air transport industry is going through a phase of major structural and operational changes following many years of theoretical planning. CDA is only a small part of these changes but the benefits can be substantial and worth the effort.

\section{CONCLUSION}

Initial measurement conducted in cooperation with Croatia Airlines and CroControl showed that benefits of the CDA procedures are within the limits defined by ICAO and EUROCONTROL documents. For detailed results a more thorough research is needed, using active noise measurement on the ground and in the aircraft itself combined with the larger number of flights. This kind of research would include a cost/benefit assessment of the CDA procedures implementation. It would also define guidelines and steps that need to be taken for complete CDA implementation within the Croatian airspace. One of the more important results of such research would be setting up company standards and recommended practices regarding CDA, not only for Croatia but for other airports in Europe as well.

Due to the relevant data gathered by specific measurements on the ground and in the air as well as simulators, this research will be a foundation upon which the CDA implementation plan will be built in case that the CDA procedures are adopted in Croatia.

Also, two other directions of research are possible, first, in coordination with EUROCONTROL centre for simulations which has already shown considerable interest, and second, which is monitoring performance as part of the fourth phase of CDA implementation.

This kind of research initiates close cooperation and coordination of all stakeholders in the Croatian airspace, it creates a connection between science and economy and, finally, it develops the air traffic and the Republic of Croatia as a whole.

\section{ACKNOWLEDGMENTS:}

This study is part of the project No. 135-1352339-2349 supported by the Ministry of Science, Education and Sports of the Republic of Croatia.
Dr. sc. DORIS NOVAK

E-mail: doris.novak@fpz.hr

Dr. sc. TINO BUCAK

E-mail: tino.bucak@fpz.hr

TOMISLAV RADIŠIĆ, dipl. ing.

E-mail: tomislav.radisic@fpz.hr

Sveučilište u Zagrebu, Fakultet prometnih znanosti

Vukelićeva 4, 10000 Zagreb, Republika Hrvatska

\section{SAŽETAK}

\section{OPTIMIZACIJA NAVIGACIJSKIH PROCEDURA U SVOJSTVU UNAPRJEĐENJA PROMETNO-TEHNO- LOŠKIH ZNAČAJKI ZRAKOPLOVA A319/320}

Ovaj se članak bavi optimizacijom navigacijskih putanja komercijalnih zrakoplova A-319/320 koji se nalaze u floti Croatia Airlines-a u završnoj (prilaznoj) fazi leta, a koja se očituje u smanjenju količine potrebnog goriva za let, smanjenju emisije štetnih plinova $i$ smanjenju područja na zemlji zahvaćenog bukom zrakoplova u prilazu. Tehnološki proces zračnog prijevoza, kao proces stvaranja usluge sredstvima zračnog prometa, predmet je istraživanja tehnologije zračnog prometa. Sam proces prijevoza putnika i robe zračnim putem općenito obilježava značajka da se u tom procesu savladavaju prostorne razlike $i$ da se sam proces odvija u prostoru i nije vezan uz određeno mjesto (osim pojedinih radnji i poslova kao što su utovar istovar robe, ukrcaj i iskrcaj putnika i sl). Sukladno tome, kako bi se uspješno savladale prostorne razlike potrebno je razviti i primjenjivati navigacijske procedure i postupke u letenju koje omogućuju maksimalnu iskoristivost zrakoplova ili flote zrakoplova. Na taj način se neposredno povećava ekonomičnost kao jedno od načela prometne tehnologije - zrakoplovnoga prijevoznika, koji je uz zračne luke i službu kontrole letenja sudionik u prometnom procesu. Navedene navigacijske procedure u izravnoj su vezi s prometno-tehnološkim značajkama zrakoplova komercijalne namjene, što je zapravo jedan od sadržaja istraživanja tehnologije prijevoza.

\section{KLJUČNE RIJEČI}

navigacijske procedure, prilaženje s kontinuiranim snižavanjem, zračni promet, ekologija

\section{LITERATURE}

[1] Radačíc, Ž., Suić, I., Škurla Babić, R.: Tehnologija zračnog prometa I, University of Zagreb, Faculty of Transport and Traffic Sciences, Zagreb, 2008

[2] Anon: Local Convergence and Implementation Plan for Croatia, LCIP 2007-2011 HR, Edition 2007-2011, Eurocontrol, June 2007

[3] Paulson, G.: Capacity and Safety, Air Traffic Technology International, 2006, p. 36-41

[4] Anon: Review of Noise Abatement Procedure Research \& Development and Implementation Results - Discussion of Survey Results, ICAO, 2007

[5] Anon: Flight Efficiency Plan - Fuel and emissions savings, IATA / Eurocontrol / CANSO, August 2008

[6] Novak, D. et al.: Analysis of influence of navigation procedures on the reduction of aircraft noise during final 
approach, Inter-noise 2008, Shanghai, China, 26-29 October 2008

[7] Anon: CDA Implementation Guidance Information, Eurocontrol, August 2007

[8] Anon: Continuous Descent Approach on an Airbus Perspective, Group of experts, ECAC 16-th meeting, Monaco, 27-28 March 2003, ANCAT/60(Inf.)-WP/6

[9] Anon: Performance Based Navigation Manual, Version 5.1, RNP Special Requirements Study Group, ICAO, March 2007

[10] Anon: Navigation Application \& Navaid Infrastructure Strategy for the ECAC Area up to 2020, Eurocontrol 2008

[11] Anon: Manual on required Navigation Performance (RNP), Doc. 9613-AN/937, ICAO, Second Edition 1999
[12] Anon: Future Standards on Navigation, RTCA SC-181/ /EUROCAE WG 13, 1999

[13] Shepherd, L.: A welcome arrival, Air Traffic Technology International, 2009, pp. 34-35

[14] Galloti, V. P.: The Future Air Navigation Systems (FANS), Ashgate, UniversityPress, Cambridge, UK, 1998, p. 94.

[15] Anon: Introduction of Precision RNAV (P-RNAV) in Croatian Terminal Airspace, Air Information Circular, A01/04, Croatia Control Ltd., February 2001

[16] Anon: Noise from arriving aircraft - an industry code of practice, Department for Transport, Crown copyright, November 2006 